\title{
УДК 514.115:744.43:378.147
}

Ленчук Іван Григорович

доктор педагогічних наук, професор, професор кафедри методики навчання математики, фізики та інформатики

Житомирський державний університет імені Івана Франка, м. Житомир, Україна

lench456@gmail.com

Франовський Анатолій Цезарович

кандидат фізико-математичних наук, доцент, декан фізико-математичного факультету

Житомирський державний університет імені Івана Франка, м. Житомир, Україна

integral52@mail.ru

\section{ТИПІЗАЦІЯ І КОМП'ЮТЕРНЕ МОДЕЛЮВАННЯ КОНСТРУКТИВНИХ ЗАДАЧ ПЛАНІМЕТРІЇ: МЕТОД КІЛ}

\begin{abstract}
Анотація. Презентована стаття стосується задач на побудову в планіметрії. Розкрито проблему становлення, в тих хто вчиться стереотипів, ефективного, економного в часі візуального представлення на екранах сучасних комп'ютерів алгоритмів їх розв'язання. Використано універсальний авторський прийом фрагментарної типізації задач на метод кіл. Вирізнено основні задачі даного типу з наступним їх наповненням складовими. Раніше розроблені педагогічні програмні засоби (частково, GeoGebra) гарантують оптимальну реалізацію ходу побудов. Їх динамічні характеристики і конструктивні можливості - якісне наочно-образне проведення етапів «доведення» $\mathrm{i}$ «дослідження».
\end{abstract}

Ключові слова: метод кіл; побудова; конструктивна планіметрія; спряження; аналіз; діяльнісний підхід; моделювання; педагогічні програмні засоби; типізація.

\section{1. ВСТУП}

Постановка проблеми. Не секрет, що майбутня діяльність багатьох випускників ЗОШ може бути пов'язана з математикою й вони, як правило, вивчають їі глибше, користуючись допоміжними джерелами інформації. Проте ні учні, ні студенти, ні вчителі математики не мають у достатньому обсязі методичної літератури, де розглядалися б задачі на побудову. За минулі кілька десятків років в Україні видано лише один методичний [3] й один навчальний [2] посібники з означеної тематики; останній - обмеженим тиражем. Разом із тим, навчання студентів спеціальності «Математика», учнів у школах із профільним вивченням дисципліни, робота з учителями в інституті післядипломної педагогічної освіти спонукають нас замислитися, чому в опануванні геометрії одним із найважчих моментів є розв'язування задач на побудову.

Проаналізувати всі причини складно. Наголосимо на чотирьох: 1) конструктивним задачам мало відводиться місця у програмах, отже і в підручниках їх недостатньо. Й це дивує фахівців, оскільки виключно такі пропозиції є суто геометричними, а тому найбільш затребуваними в розумовому розвитку засобами найпершої з наук; 2) традиційно так склалося, що конструктивізм, як форма проведення операцій із геометричними фігурами, не пропагується в умовах аудиторних занять, у зв'язку з чим немає обгрунтованої методологічної системи навчання його методам і прийомам; 3) учні, студенти, а іноді й самі вчителі недооцінюють етап аналізу, не розуміють вартісної ролі окремих етапів в опануванні геометрії, не зважають на зв'язки і відношення між ними в цілісній схемі розв' язування задач; 4) поки що в научанні геометрії в цілому мало враховуються потенційні можливості сучасних інформаційно-комунікаційних технологій (IКT).

Аналіз останніх досліджень і публікацій. Традиційна методологія домінування формально-логічного підходу у викладанні й учінні геометрії і помітного нехтування 
конструктивно-генетичним методом глибоко помилкова. Уміння вести пошук шляху розв'язування задачі, обгрунтовувати істинність результату, досліджувати умови існування і ситуаційні варіації уявлюваних рисункових конструкцій є вищим проявом особистісної творчості. Ще півстоліття тому незаперечний авторитет серед геометрів акад. Четверухін М. Ф. стверджував: «Геометричні задачі на побудову є настільки істотним фактором математичної освіти, щзо на викладання цьього розділу в середній школі має бути звернена серйозна увага» [19, с. 3]. Цю ж думку відстоювали відомі російські геометри Б. І. Аргунов і М.Б. Балк: «Геометричні побудови можуть зіграти серйозну роль у математичній підготовиі школяра. Жоден вид занять не надає, мабуть, стільки матеріалу для розвитку ініціативи і логічних навичок учня, як геометричні задачі на побудову. Ці задачі як звичайно не припускають стандартного підходу до них і формального сприйняття їх учнями» [1, с. 10]. Категорично і більш предметно висловлюється з цього приводу знаний в Україні вчений М. І. Бурда: « ... важливість задач на побудову обумовлюється особливостями наукової структури курсу геометрії 7-9 класів, провідним компонентом якої є конструктивізм: майже всі геометричні поняття означуються конструктивно; доведення всіх теорем спирається на використання фігур, реальне існування яких можна відтворити побудовою. Отже, задачі на побудову мають розвивати в учнів конструктивний підхід до осмислення всього комплексу геометричних знань, а не лише формувати конструктивні навички розв'язування задач» [3, с. 3]. Аргументована, переконлива позиція акад. Бурди М. І. відкидає консервативну думку про маловартість і недоречність планіметричних побудов у школі!

До короткого переліку найпростіших, не означуваних фігур геометрії належить, як відомо, пряма лінія. Однак не менш простою в розумових уявленнях особи, що вчиться, у iii зображеннях на кресленні, у повсякденному «баченні» і практичному застосуванні $€$ означувана лінія, яку називають колом. Пряму, до речі, неважко уявити колом iз нескінченно великим радіусом. Тож не дивно, що лінійку і циркуль вважають найпершими, класичними інструментами розв'язування задач на побудову. Жоден із цих засобів навчальної і виробничої діяльності не має суто геометричних переваг перед іншим. Як-от, нібито неспоріднені перетворення фігур: паралельне перенесення, виконуване лінійкою, і поворот навколо точки на заданий кут, де «першу скрипку грає» циркуль, мають одну і ту ж природу, відрізняючись лише формально [9, с. 16-19].

Коли говорять про конструктивні задачі, що розв'язуються з активною участю кіл, то мають на увазі такий тип задач, у яких у візуальному виконанні покрокових операцій на шляху до результату не завжди діє напряму евристичний припис методу геометричних місць точок (ГМТ). Часто більш переконливим засобом побудови виступають «працюючі» кола, точніше пучки і в'язки кіл, тобто залучаються до діла радикальні вісь і центр $[1,8,19]$. Усе ж і тут відомі найпростіші ГМТ відіграють неабияку роль.

У навчальних планах ВПНЗ і, тим більше, ЗОНЗ якраз класу задач «на кола» приділяють надто мало уваги. Причин кілька. По-перше, потрібна специфічна теоретична підготовка i, по-друге, треба мати усталені навички графічної роботи з колами, що пов' язані певними закономірностями, а це здобувається непросто. 3 іншого боку, виважено поданий метод примножує знання і вміння суб' єкта освітнього процесу, збагачує інтелектуально, додає професіоналізму. Крім того, задля відчутного спрощення фактичних операцій, виграшу в часі, ефективного, якісного, динамічного представлення задач зримими моделями, реалії сьогодення дозволяють скористатися потужними комп'ютерами й уже розробленими і добре налагодженими ППЗ навчання.

Дослідження, присвячені інноваційним педагогічним технологіям і, в першу чергу, створенню і розробці нових методик і комп'ютерних технологій навчання, науково повно проведені вітчизняними вченими: Жалдаком М. І., Крамаренко Т. Г., Морзе Н. В., Раковим С. А., Рамським Ю. С., Співаковським О. В., Триусом Ю. В. та ін. 
Акад. Жалдак М. І. підкреслює: «В основу інформатизації навчального процесу слід покласти створення і широке впровадження в повсякденну педагогічну практику нових комп'ютерно оріснтованих методичних систем навчання всіх без винятку дисциплін на принципах поступового і неантагоністичного, без руйнівних перебудов i реформ, вбудовування інформаційно-комунікаційних технологій у діючі дидактичні системи, гармонійного поєднання традиційних і комп'ютерно орієнтованих технологій навчання, не заперечування і відкидання здобутків педагогічної науки минулого, а, навпаки, їх удосконалення і посилення, у тому числі й за рахунок використання досягнень у розвитку комп'ютерної техніки і засобів зв'язку» [5, с. 4].

Серед ППЗ інтегрованого характеру, призначених для ефективного використання у вивченні тих чи інших розділів математики і цілком придатних для розв'язування геометричних задач конструктивно-генетичним методом, варто вирізнити такі програмні засоби: GRAN1, GRAN-2D, GRAN-3D, Derive, DG, GeoGebra, SAGE, SciDAVis та ін.

У статті [11] для поміркованої, фахової комп'ютеризації сформованих типів задач на побудову нами, як робочий інструмент, обрано зручний, простий i надійний у використанні програмний засіб GRAN-2D. Зараз ми рекомендуємо ознайомитися 3 реальними можливостями в цій сфері іншого програмного засобу - GeoGebra, доступного користувачам нескладним інтерфейсом. Це - захоплююча, одна 3 найбільш популярних динамічних геометрій, незамінна помічниця у здобутті стабільних навичок наочного представлення фігур, у поясненні нового матеріалу, у самостійному ознайомленні з навчальним матеріалом не лише геометрії, але й алгебри і математичного аналізу. У ній реалізовано комплекс найпростіших побудов і багато основних побудов (НП і ОП). Вона «навчена» моделювати перетворення геометричних фігур, вимірювати довжину відрізків, градусну міру кутів, площу фігур тощо. Програмні можливості GeoGebra дозволяють створювати макроси, автоматизовано писати підпрограми, експортувати дані у формат HTML5. Чудовою особливістю ППЗ є можливість подвійного подання об'єктів: усякий вираз у вікні алгебри відповідний об'єкту у вікні геометрії і навпаки $[7,16]$.

Зумисне, з наголосом додамо. Тип задач на прямі і кола має найширше застосування у кресленні, інженерній та комп’ютерній графіці, а отже - в техніці $[13,18]$. Наприклад, у найпершому розділі «Геометричне креслення» детально, із прикладами практичного вираження розглядають тему «Спряження». Нагадаємо, плавний перехід однієї лінії в іншу є їх дотиком. Спряження — це плавний перехід однієї лінії в іншу, виконаний за допомогою проміжної (третьої) лінії. Найчастіше за проміжну лінію обирають коло (у випадку побудови спільної дотичної двох кіл - пряму). Операція побудови спряжень спирається на такі суто геометричні факти: 1) перехід кола у пряму лише тоді буде плавним, коли пряма в точці переходу є дотичною до кола; 2) перехід з одного кола в інше лише тоді буде плавним, коли кола в точці переходу мають спільну дотичну.

Для певності наголосимо: «Креслення як навчальний предмет (у вищій і середній школі) виділялось із геометричної науки поступово, під впливом вимог техніки» [12, с. 3].

Отже, з огляду на сказане, окремими, стрижневими у фрагментарній типізації задач на побудову ми обираємо задачі на дотик (спряження) кіл і прямих із наступним його наповненням складовими, спорідненими за змістом і технологією розв'язання. Наразі поставимо за мету статті висвітлення методичних і суто практичних аспектів проблеми якісної типізації задач планіметрії (креслення) й ефективного застосування сучасних IКТ в їх наочно-образному моделюванні діяльнісним конструктивно-генетичним методом. 


\section{2. МЕТОДИ ДОСЛІДЖЕННЯ}

Науково-методичні дослідження проблемних питань навчання геометрії велися у процесі довготривалої викладацької практики в колективах студентів педагогічних університетів, учителів в інститутах післядипломної педагогічної освіти, учнів у старших класах із профільним рівнем опанування математики.

Для комплексної реалізації поставлених цілей здійснено аналіз педагогічної ситуації: з'ясовано професійно-пізнавальні інтереси і ціннісно-смислову орієнтацію суб'єктів навчання, встановлено міжпредметні зв'язки споріднених дисциплін, узагальнено власний педагогічний досвід і досвід колег, опрацьовано, класифіковано літературні й електронні джерела і відомі ППЗ, використано методи аналізу і синтезу, спостереження і порівняння, структуровано і строго систематизовано навчальний процес.

Як наслідок, на освітянській ниві у сфері першонауки запроваджено обгрунтований психофізіологами і перевірений експериментально спосіб геометризації, візуального унаочнення й графічного (графоаналітичного) представлення бінарними моделями шляхів вирішення різних за способами розв'язання і різного рівня складності геометричних пропозицій. Професійно прогнозовані алгоритми закономірних покрокових операцій чітко реалізовуються на екранах дисплеїв сучасних комп’ютерів.

\section{3. РЕЗУЛЬТАТИ ДОСЛІДЖЕННЯ}

Що означає розв'язати задачу на побудову? Пряма і не до кінця осмислена відповідь очевидна - побудувати шукану фігуру (так відповідають завжди). Однак, що означає «побудувати»? 3 виконавського погляду все просто: потрібно взяти в руки лінійку і циркуль i, знаючи певну послідовність дій, змоделювати зображенням («від руки» чи на комп’ютері) замовлену фігуру. 3 погляду геометрії як науки, це означає, що необхідно звести задачу до низки вже розв'язаних задач або безпосередньо до НП та ОП, істинність кожної з яких зумовлена теоретично. Наведені міркування індукують таке означення: розв'язати задачу на побудову - означає перейти від неявного означення шуканої фігури (умови) до ї̈ явного означення, тобто до конструкиії фігури.

Цей перехід якраз і $є$ (точніше називається) аналізом - першим етапом на шляху до візуального представлення шуканої фігури. Отож бо, аналіз задачі виступає основним етапом іiі розв'язування, а не $\epsilon$ чимось надуманим. Від того, наскільки професійно проведено етап аналізу залежить правильність результату. Аналіз в явному вигляді містить вичерпний алгоритм побудови - уміло скомпоновану послідовність простих, усвідомлених і легко контрольованих конструктивних операцій, що дозволяє за допомогою скінченного числа кроків, скінченного числа графічних дій, за скінченний час одержати якісне зображення конструкції (що, власне, і є привілеями конструктивногенетичного методу). Таким чином, розв'язати задачу на побудову - означає правильно зробити ї̈ аналіз. Якщо вчитель не зможе переконати в цьому учня, то останній, безумовно, не навчиться розв'язувати такі задачі.

Пам'ятатимемо, що в деталізованому переліку кроків будь-яка діяльність лінійкою і циркулем реально здійснюється з використанням скінченної кількості операцій, кожна 3 яких є виключно однією з дев'яти НП. Останні компонують у типові, що часто зустрічаються комбінації, тобто зводять до відомих і нескладних конструктивних задач (уже розв'язаних раніше), які називають ОП [9].

Елементарними в розглядуваному типі є задачі на спряження двох прямих, прямої і кола та двох кіл дугою кола заданого радіуса. Їх, за домовленістю, також не завадить 
віднести до списку ОП. Ці ж задачі стають візуально більш привабливими (цікавішими), набувають глибшого змісту i, навіть, потребують проявів творчості й інтуїції в міркуваннях, коли умовою задається не радіус дуги спряження, а точка спряження на одній із накреслених ліній: чи то на прямій, чи на колі.

Навчальні динамічні моделі нижче розв'язаних нами задач, виконаних у програмі GeoGebra, подаватимемо в установленому порядку з екрана ПК.

Задача № 1. Побудувати спряження прямої з колом дугою кола, якщо точку спряження задано на колі (рис. 1, 3).

Задача № 2. Побудувати спряження двох кіл дугою кола, якщо точку спряження задано на одному з цих кіл (рис. 2, 4).

Задача № 3. Побудувати спряження прямої з колом дугою кола, якщо точку спряження задано на прямій (рис. 5-7).

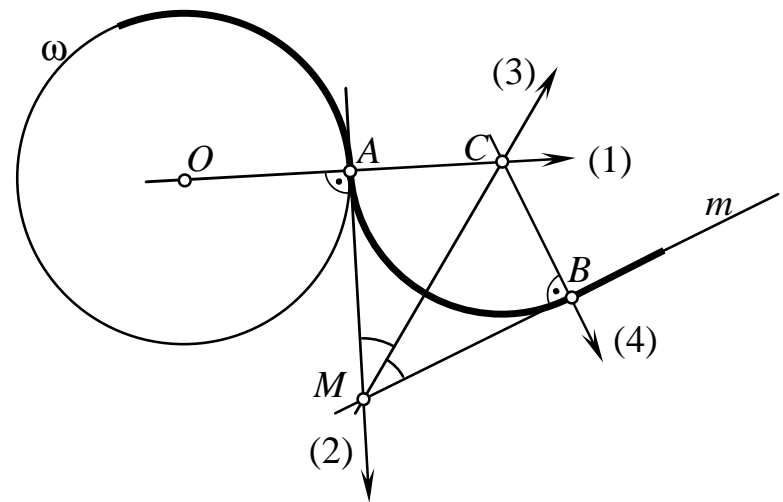

Рис. 1. Спряження кола і прямої

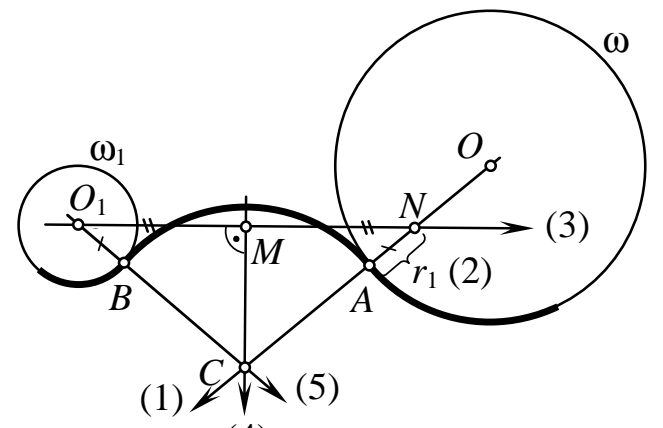

(4)

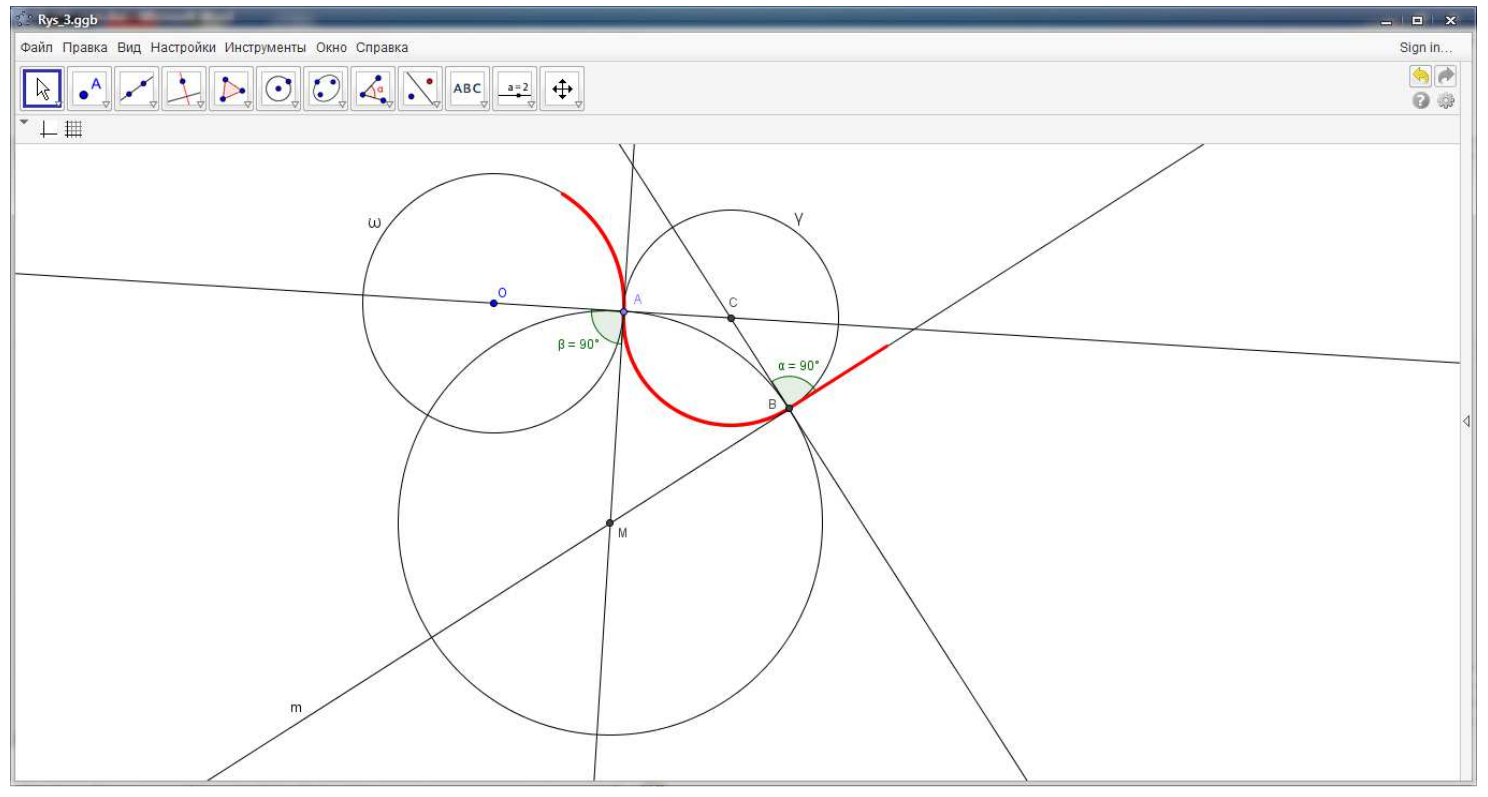

Рис. 3. Фрагмент зображення GeoGebra до задачі № 1

Немає нагальної потреби описувати етап аналізу в цих задачах, оскільки побудови на зображеннях навіч змодельовані стрілками і цифрами (у дужках), а традиційно вживана геометрична символіка відображає відповідні графічні операції. Покрокові алгоритми дій, як зазвичай, реалізовано методом ГМТ, а потім (із застосуванням ППЗ GeoGebra) ще й методом кіл. Перерахуємо ОП, які довелося використати у таких відносно простих 
ситуаціях: 1) проведення дотичної до кола в заданій на ньому точці; 2) побудова бісектриси кута; 3) опускання перпендикуляра з точки на пряму; 4) відкладання від точки на промені відрізка, рівного даному; 5) побудова серединного перпендикуляра відрізка; 6) відшукання суми (різниці) двох відрізків. На моделях: точка $A \in$ заданою, точка $B-$ побудованою, а $(C, C A=C B)$ - шукана дуга спряження заданих прямої і кола (двох кіл).

Te, що кожну із задач можна також з успіхом розв'язати методом кіл, цікаво і суть важливо. Розглянемо більш детально, наприклад, задачу під номером 3 (рис. 6).

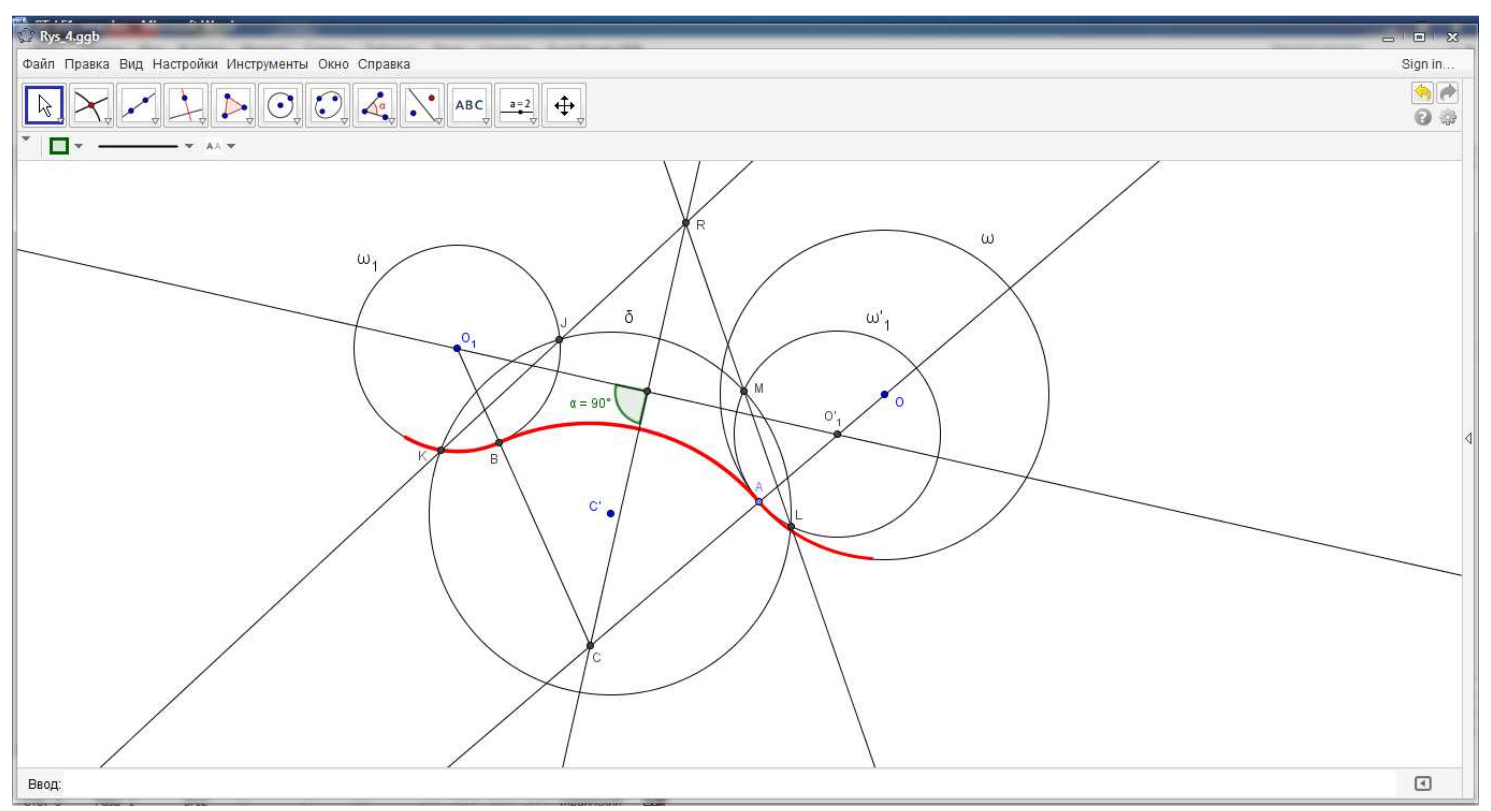

Рис. 4. Фрагмент зображення GeoGebra до задачі № 2

Розв'язування. Шукане коло належить параболічному пучку з віссю $M N$ i центром $A$. Нехай $\omega-$ будь-яке коло цього пучка (1), що перетинає задане коло $\Gamma$ у двох точках $B$ і $C$ (2). Точка $F=B C \cap M N \in$ радикальним центром (3) трійки кіл $\omega$, $\Gamma$ i $\Gamma_{1}\left(\Gamma_{2}\right)$. Тому дотична з точки $F$ до кола $\omega(4)$ також буде дотичною до шуканого кола $\Gamma_{1}\left(\Gamma_{2}\right)$. Провівши допоміжне коло $\omega_{0}(F, F A)$, одержимо два можливих розташування точок дотику шуканого кола до заданого (5). На рисунку $\Gamma_{1}$ i $\Gamma_{2}-\partial в а$ можливі розв'язки (6).

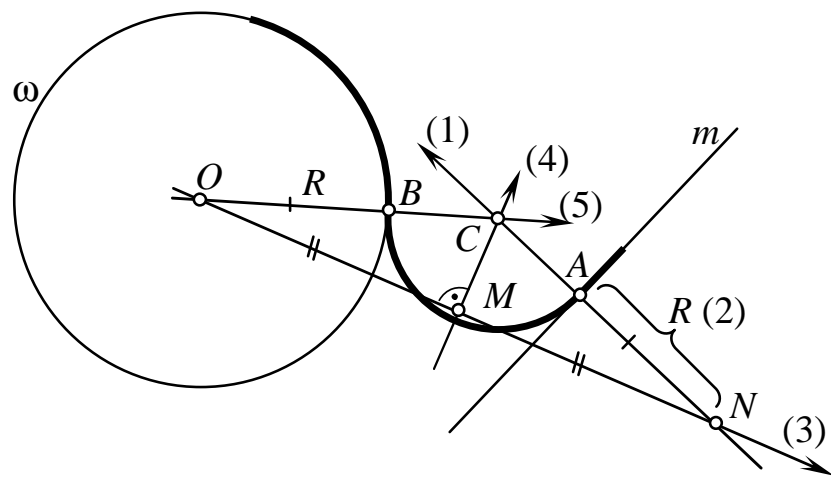

Рис. 5. Спряження прямої і кола

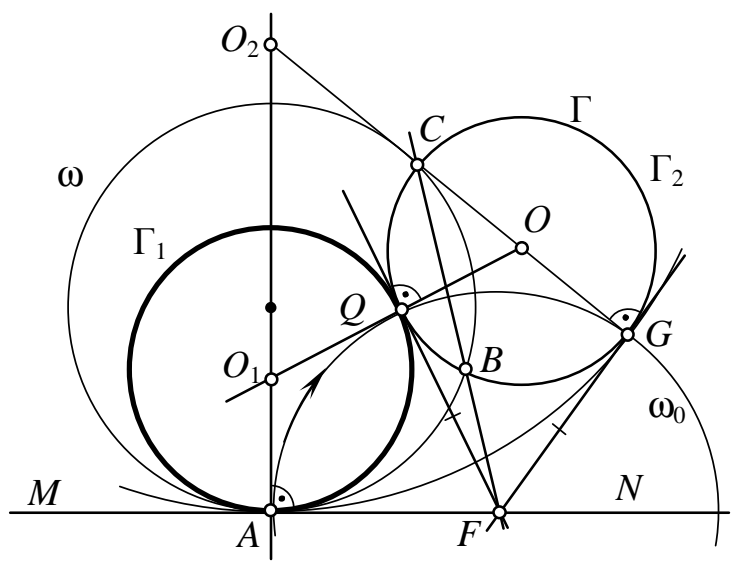

Рис. 6. Параболічний пучок кіл 
Тут принагідно використано такі ОП: 7) проведення перпендикуляра до прямої в заданій на ній точці; 8) побудова радикальної осі параболічного пучка кіл; 9) побудова із зовнішньої точки дотичної до кола.

Цьому типу належать ще дві задачі, у пошуку розв' язків яких до вже залучуваних ОП додаються: 10) побудова серединного перпендикуляра відрізка; 11) побудова радикальної осі еліптичного пучка кіл.

Задача № 4. Через дві дані точки $A$ і $B$ провести коло так, щоб воно дотикалося даної прямої $m$ (рис. 8,10 ).

Задача № 5. Побудувати коло, яке дотикається даного кола $\omega$ і проходить через дані точки $A$ i $B$ (рис. 9, 11).

Розв'яжемо, наприклад, 5-ту задачу, а до 4-тої додамо лише рисунок і дозволимо читачеві самостійно реконструювати алгоритм візуально змодельованих нами дій.

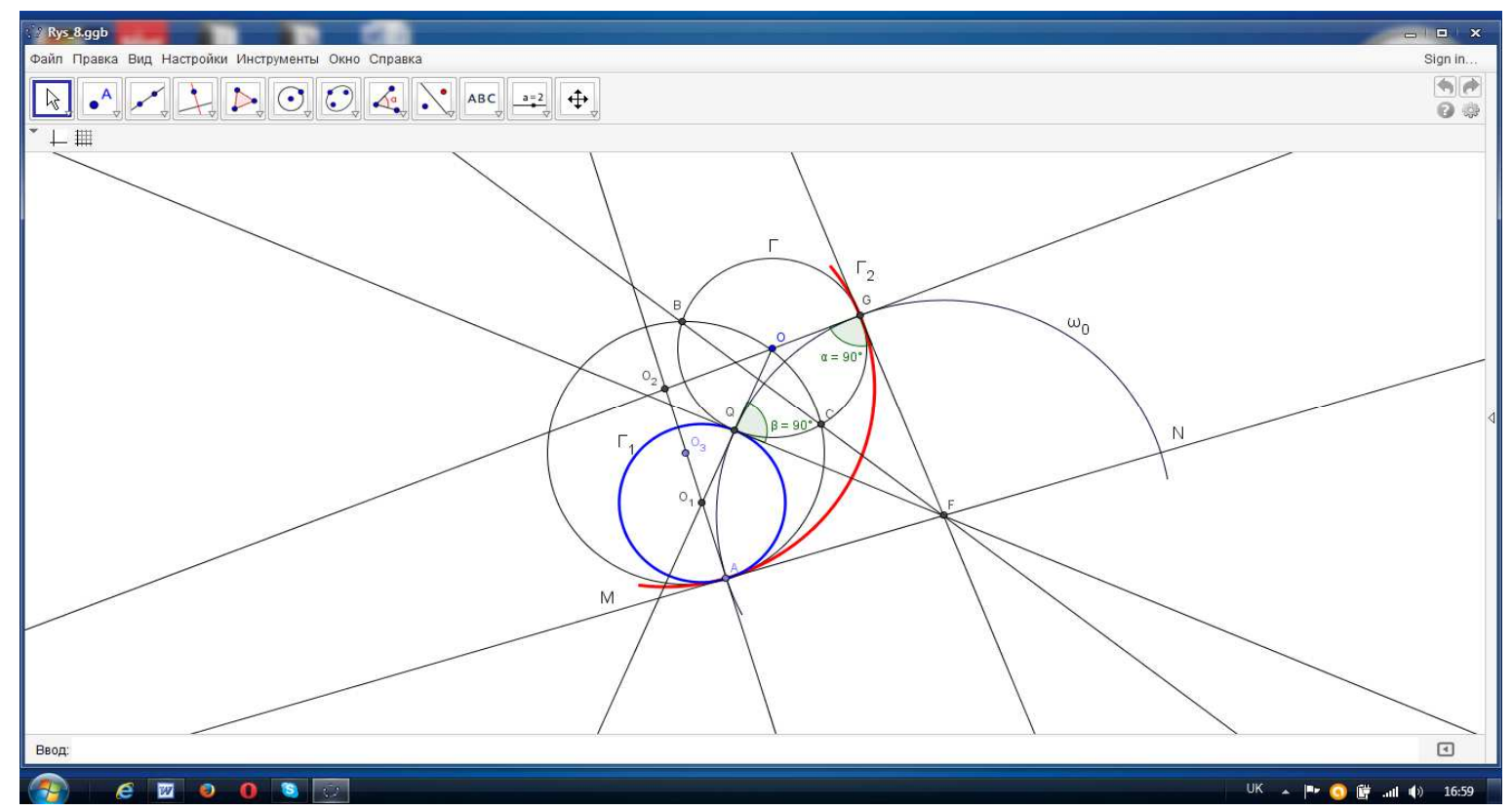

Рис. 7. Фрагмент зображення GeoGebra до задачі № 3

Аналіз. Нехай коло $\Gamma_{1}$ задовольняє умову задачі (рис. 9) - містить точки $A$ і $B$ і дотикається (у точці $Q$ ) кола $\Gamma$. Коло $\Gamma_{1}$ належить еліптичному пучку, що визначений центрами $A$ і $B$ ( $A B$ - радикальна вісь пучка (1)). Очевидно, центр шуканого кола $\left(O_{1}\right)$ належить серединному перпендикуляру $p$ відрізка $A B(2)$. Щоб остаточно з'ясувати розташування точки $O_{1}$, проведемо будь-яке коло $\omega$ цього пучка і знайдемо його точки $C$ i $D$ перетину із заданим колом $\Gamma$ (3). Напевно, точка $F=C D \cap A B \in$ радикальним центром кіл $\Gamma, \omega$ і $\Gamma_{1}$ (4). Отже, за властивістю радикального центра, матимемо: $F C \cdot F D=F A \cdot F B=F Q^{2}$. Звідси вже відомим прийомом знайдемо точку $Q$ дотику прямої, проведеної з точки $F$ до заданого кола $\Gamma(5)$, а потім, провівши $O Q$ до перетину із прямою $p(6)$, із центром $O_{1}$ радіусом $O_{1} Q$ описуємо замовлене коло (7). На моделі зображено два розв'язки. 


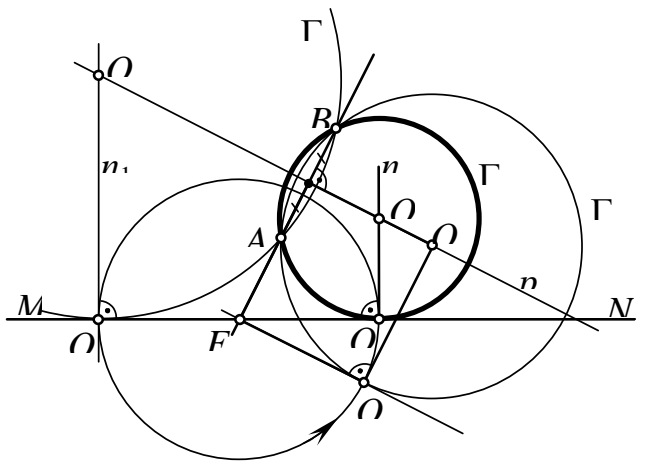

Рис. 8. Еліптичний пучок кіл

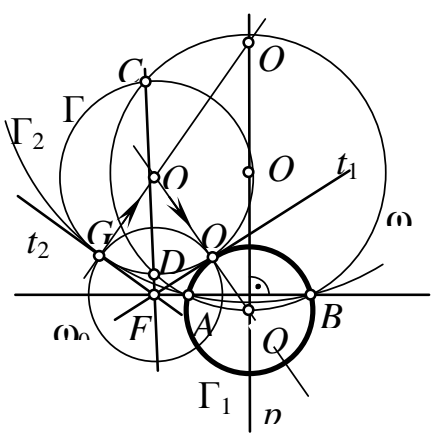

Рис. 9. Еліптичний пучок кіл

Типовими є також ще й такі дві оригінальні, а, отже, надто цікаві задачі.

Задача № 6. Через дві дані точки $A$ і $B$ провести коло $\gamma$, яке ділило б дане коло $\omega$ навпіл (рис. 12-15).

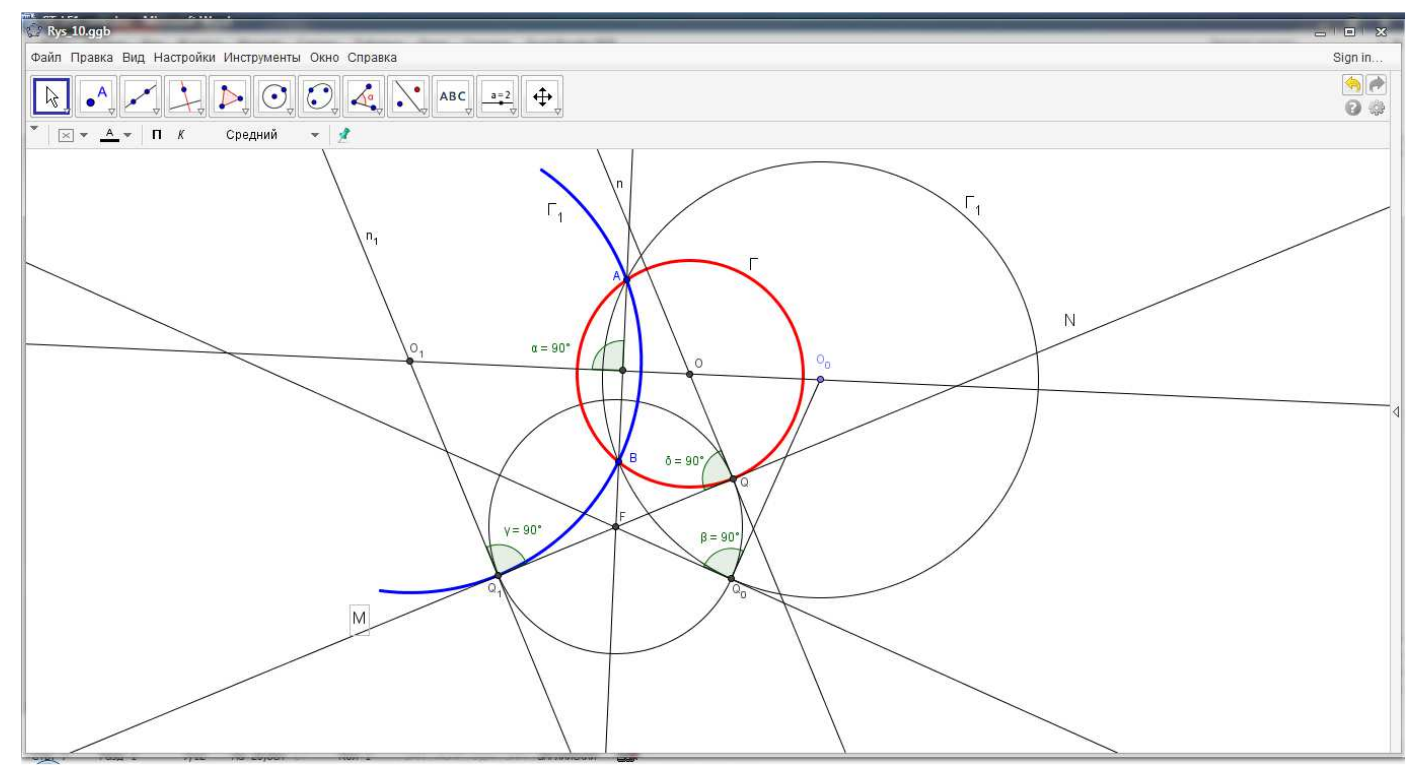

Рис. 10. Фрагмент зображення GeoGebra до задачі № 4

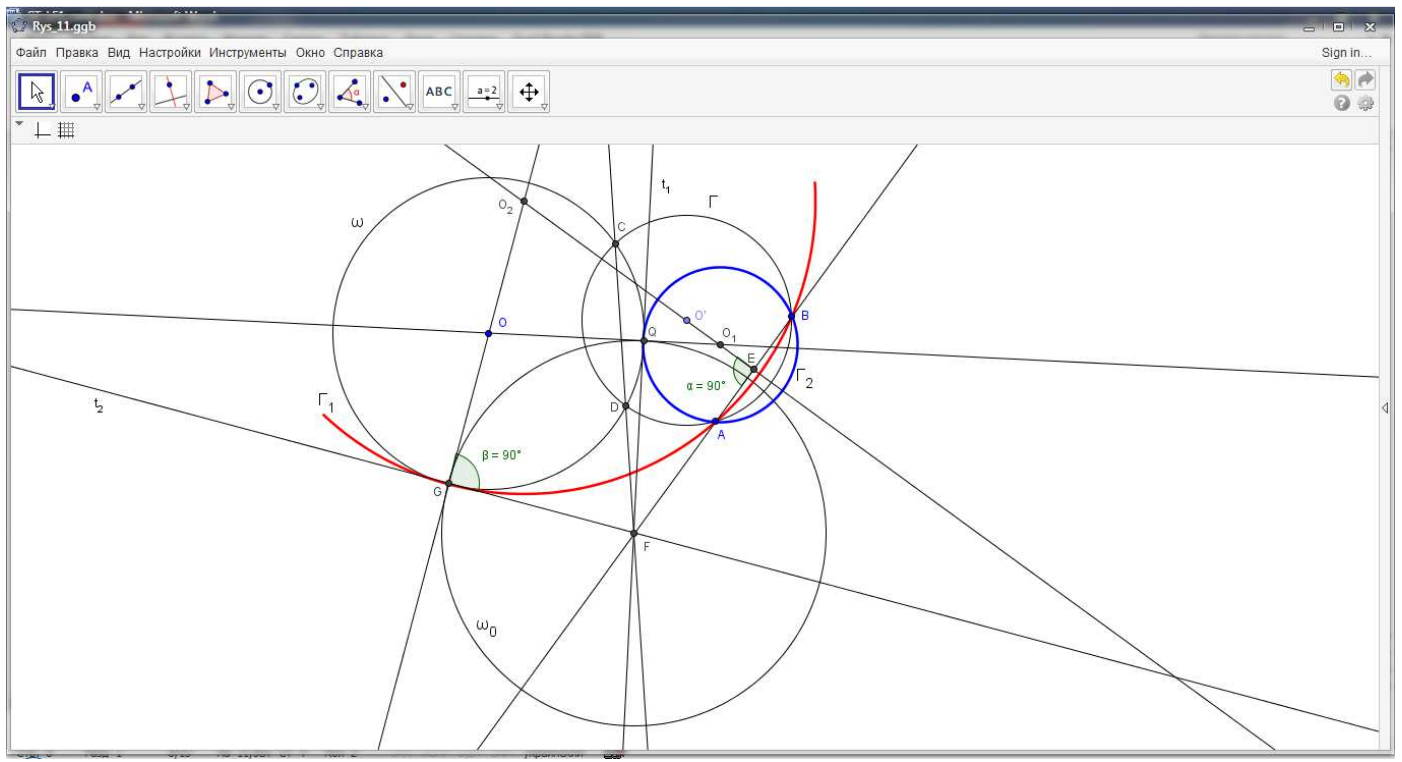

Рис. 11. Фрагмент зображення GeoGebra до задачі № 5 
Задача № 7. Через дві дані точки $A$ і $B$ провести коло $\gamma$, яке ділилося б даним колом $\omega$ навпіл (рис. 16-19).

Як на перший погляд, задачі дуже схожі. Проте, розв'язуючи їх «у лоб» методом геометричних місць точок (ГМТ), довелося б спочатку виявити в алгебричних виразах зовсім неочевидні (у розумінні пересічної особи) засоби побудов (розв'язати допоміжні задачі) i, як результат, сконструювати дві помітно різні фігури: 1) ГМТ, різниця квадратів відстаней яких від кінців відрізка є величина стала - пряму, перпендикулярну відрізку в певній його точці; 2) ГМТ, сума квадратів відстаней яких від кінців відрізка $є$ величина стала - коло певного радіуса 3 центром у точці, що є серединою відрізка. Саме вони (відповідно в першій та у другій задачах) вкупі ще з одним ГМТ - серединним перпендикуляром відрізка $A B$ - визначатимуть центр шуканого кола.

Ми ж у пошуку розв'язку першої з цих задач застосуємо метод кіл, що помітно спростить iї конструктивну складову. Розглянемо два варіанти розумових дій.

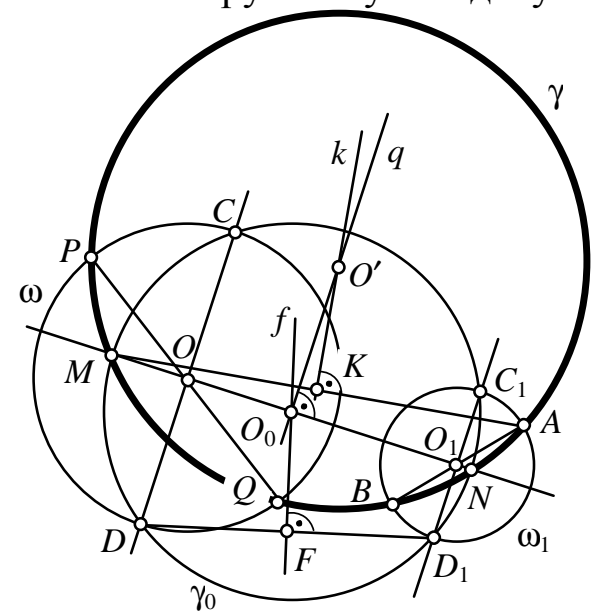

Рис. 12. Поділ накресленого кола навпіл

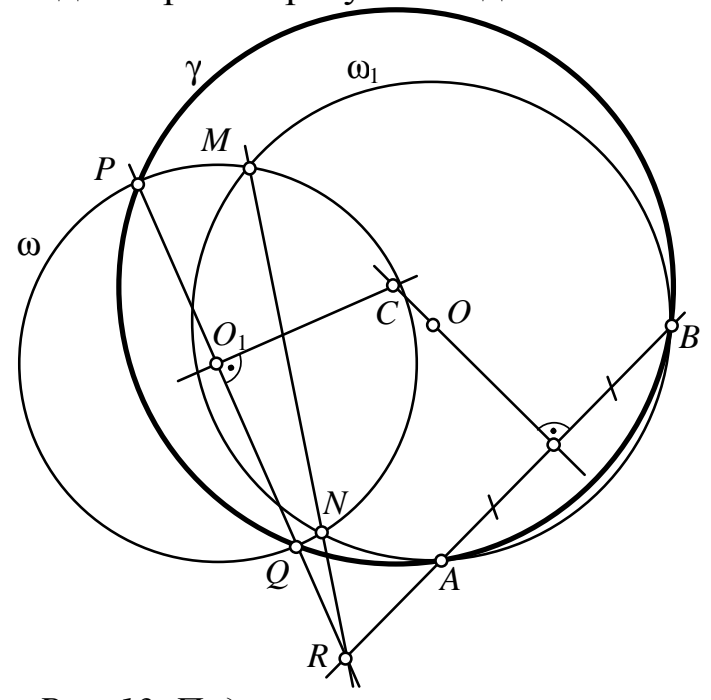

Рис. 13. Поділ накресленого кола навпіл

Варіант 1. Аналіз. Нехай коло $\gamma$ (рис. 12) задовольняє умову задачі - проходить через точки $A$ та $B$ і діаметрально перетинає дане коло $\omega$ у точках $P$ i $Q$. Відрізком $A B$, як діаметром, визначено ще одне коло $\omega_{1}$ із центром $O_{1}$, що $€$ його серединою (1). Розглянемо сукупність усіх кіл, що перетинають обидва кола $\omega$ i $\omega_{1}$ діаметрально. Відомо, що сукупність кіл, які перетинають одне коло діаметрально, утворюють еліптичну в'язку, для яких це коло є базовим [19, с. 95-96]. Тому множина кіл, які діаметрально перетинають два кола $\omega$ і $\omega_{1}, \epsilon$ перетином (чи спільною частиною) двох еліптичних в'язок із базовими колами $\omega$ і $\omega_{1}$. Доведено, що цим перетином буде пучок кіл зі спільною радикальною віссю $O O_{1}\left[19\right.$, с. 100]. Кінці діаметрів кіл $\omega$ і $\omega_{1}$, перпендикулярних осі $O O_{1}, \epsilon$ вершинами рівнобічної трапеції $C D C_{1} D_{1}$, у якої суми протилежних кутів рівні $2 d$ (2). Отже, ії вершини - точки $C, D, C_{1}, D_{1}$ - належать одному і тому ж колу $\gamma_{0}$ - представнику пучка 3 діаметром $M N$ на осі $O O_{1}$ (4). Центр кола $\gamma_{0}\left(O_{0}, O_{0} A\right)$ легко будується в перетині серединного перпендикуляра $f$ відрізка $D D_{1}$ із прямою $O O_{1}$ (3). У свою чергу, коло $\gamma$ проходить через точки $M, N, A$ і $B$, тому його центром $O^{\prime}$ буде точка перетину серединних перпендикулярів $q$ і $k$, проведених, відповідно, до відрізків $M N$ (у точці $O_{0}$ ) i, наприклад, $M A(5)$. 


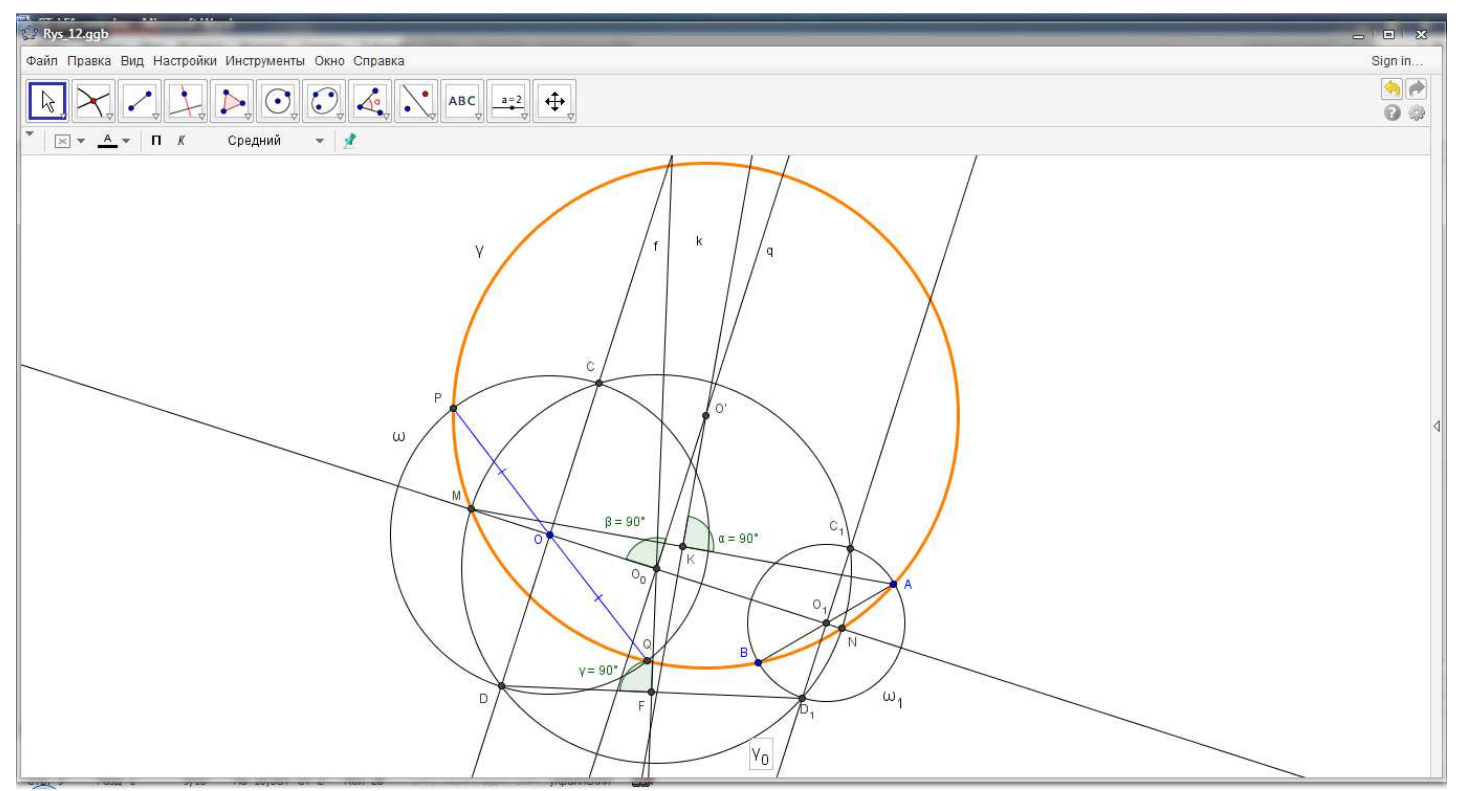

Рис. 14. Фрагмент зображення GeoGebra до задачі № 6 (в. 1)

Варіант 2. Аналіз. Нехай коло $\gamma$ (рис. 13) задовольняє умову задачі - проходить через точки $A$ та $B$ і діаметрально перетинас дане коло $\omega$ у точках $P$ і $Q$. Очевидно, що центр шуканого кола $\gamma$ слід шукати, щонайперше, на серединному перпендикулярі відрізка $A B$ (1). 3 іншого боку, будь-яке коло $\omega_{1}$, що має спільні точки $M, N$ із даним колом $\omega$ і містить ті ж точки $A$ та $B(2)$, утворює два еліптичні пучки, осями яких будуть прямі $A B(3)$ і $M N$ (4) відповідно. Вони ж, у власному перетині, висікають радикальний центр $R$ в' язки трьох зображених на рисунку кіл (5). Тому $R O$ - вісь ще одного еліптичного пучка кіл у цій в' язці, а точки $R, Q, O, P$ - колінеарні (6). Нарешті, центр $C$ кола $\gamma$ належить також серединному перпендикуляру відрізка $P Q$ у точці $O(7)$.

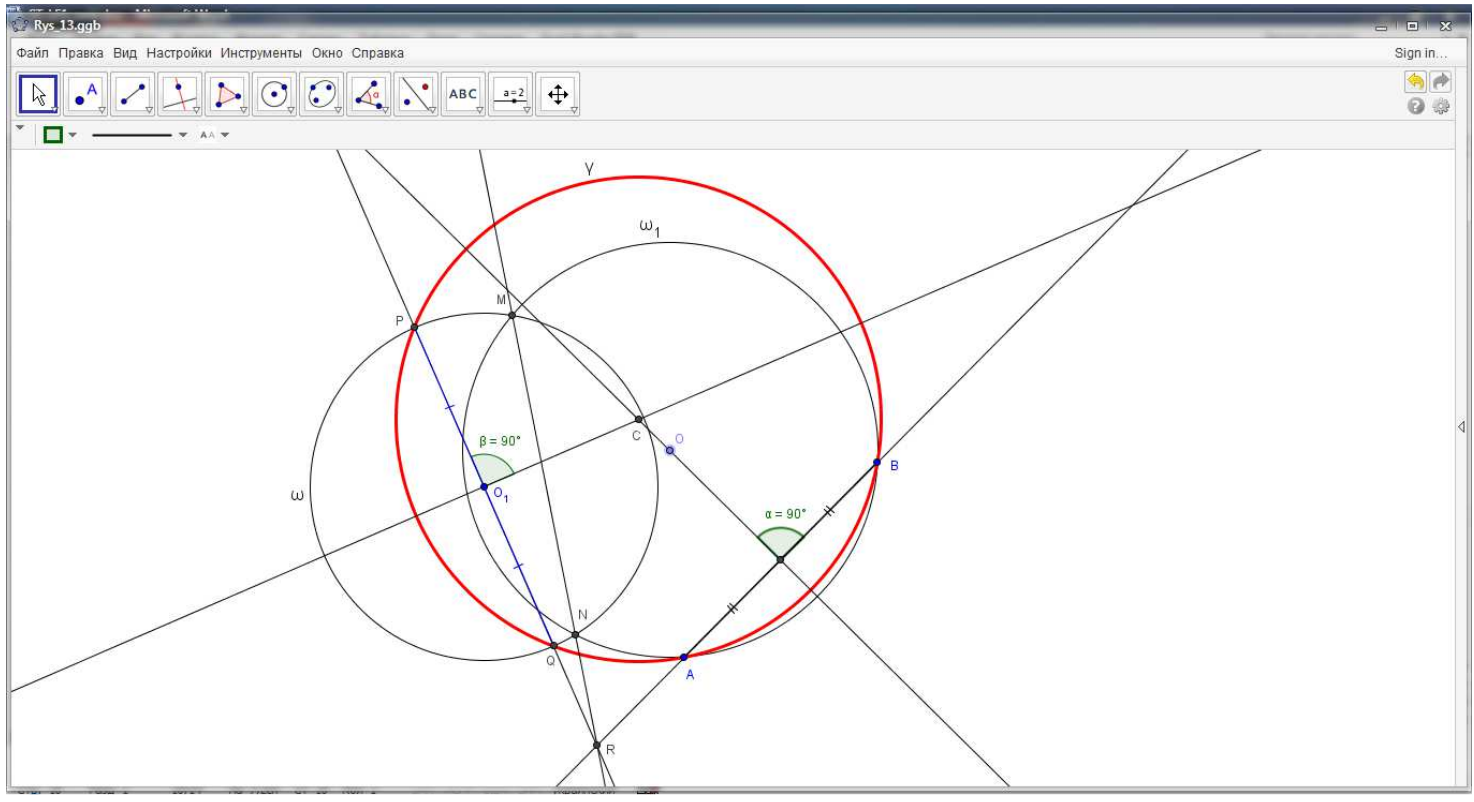

Рис. 15. Фрагмент зображення GeoGebra до задачі № 6 (в. 2)

Іншу із задач, для порівняння, розв'яжемо спочатку з проведенням аналізу так, як це передбачено методом ГМТ, а у другому варіанті знову застосуємо метод кіл. 

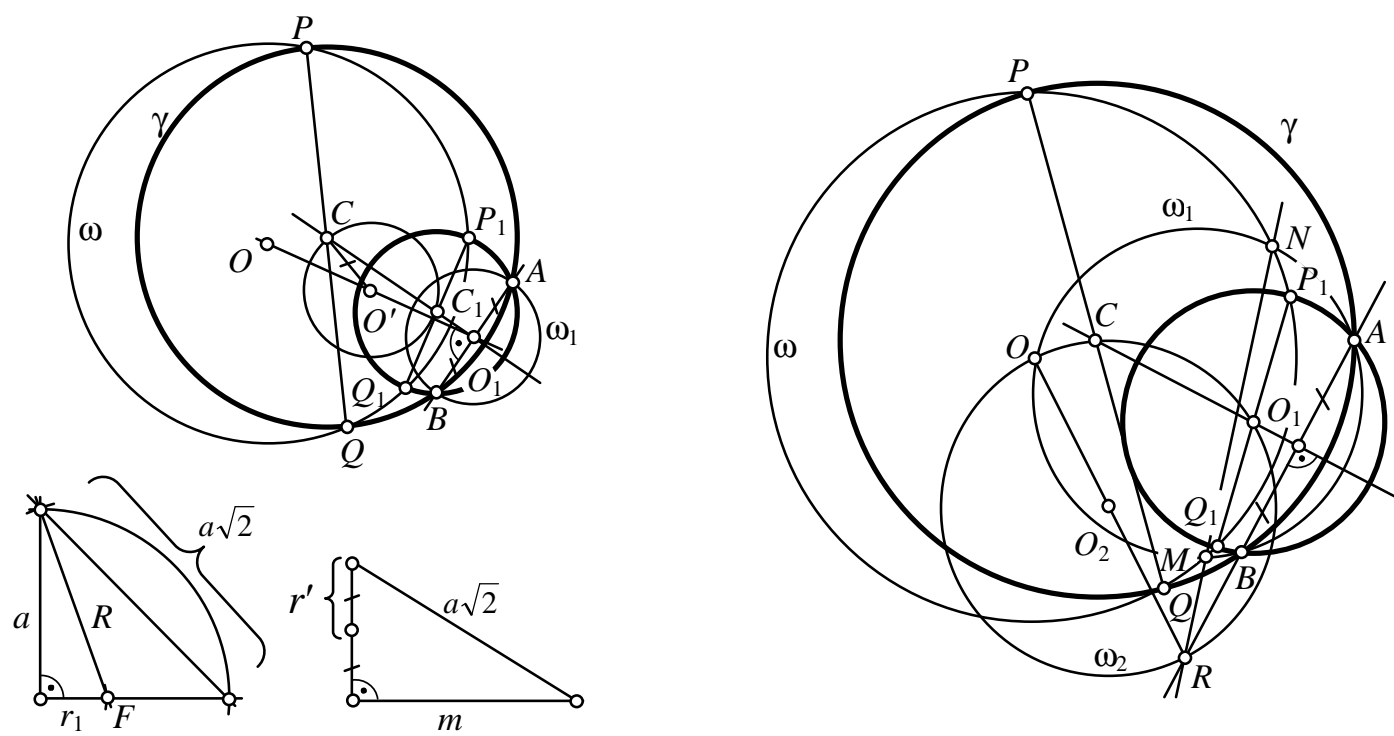

Рис. 16. Моделювання кола, яке ділилося б даним колом навпіл (метод ГМТ)

Рис. 17. Моделювання кола, яке ділилося б даним колом навпіл (метод кіл)

Варіант 1. Аналіз. Нехай коло $\gamma(C, R)$ (рис. 16) задовольняє умову задачі проходить через точки $A$ та $B$ і діаметрально перетинається даним колом $\omega(O, r)$ у точках $P$ i $Q$. Відрізком $A B$, як діаметром, визначено ще одне коло $\omega_{1}$ із радіусом $r_{1}$ і центром $O_{1}$, що є його серединою (1). Із прямокутних трикутників $O C P$ і $C O_{1} B$ будемо мати таке: $O C^{2}$ $=r^{2}-R^{2}(*), C O_{1}^{2}=R^{2}-r_{1}^{2}(* *)$. Просумувавши рівності (*) і (**), одержимо таке: $O C^{2}+$ $C O_{1}{ }^{2}=r^{2}-r_{1}^{2}=a^{2}=$ const (2). Таким чином, центр $C$ шуканого кола $\gamma \in$ перетином двох ГМТ (7): з одного боку, точка $C$ належить серединному перпендикуляру відрізка $A B(3)$, а з іншого боку, - колу з радіусом $r^{\prime}$ і з центром у точці $O^{\prime}$, яка $\epsilon$ серединою відрізка $O O_{1}$ (4). Останнє представляє собою ГМТ, сума квадратів відстаней яких від кінців відрізка $O O_{1}$ - стала величина, рівна $a^{2}(6)$. При цьому радіус $r^{\prime}$ знаходимо за формулою $r^{\prime}=\frac{\sqrt{2 a^{2}-m^{2}}}{2}(5)$, де $m-$ відстань між точками $O$ і $O_{1}[9$, c. 27-28].

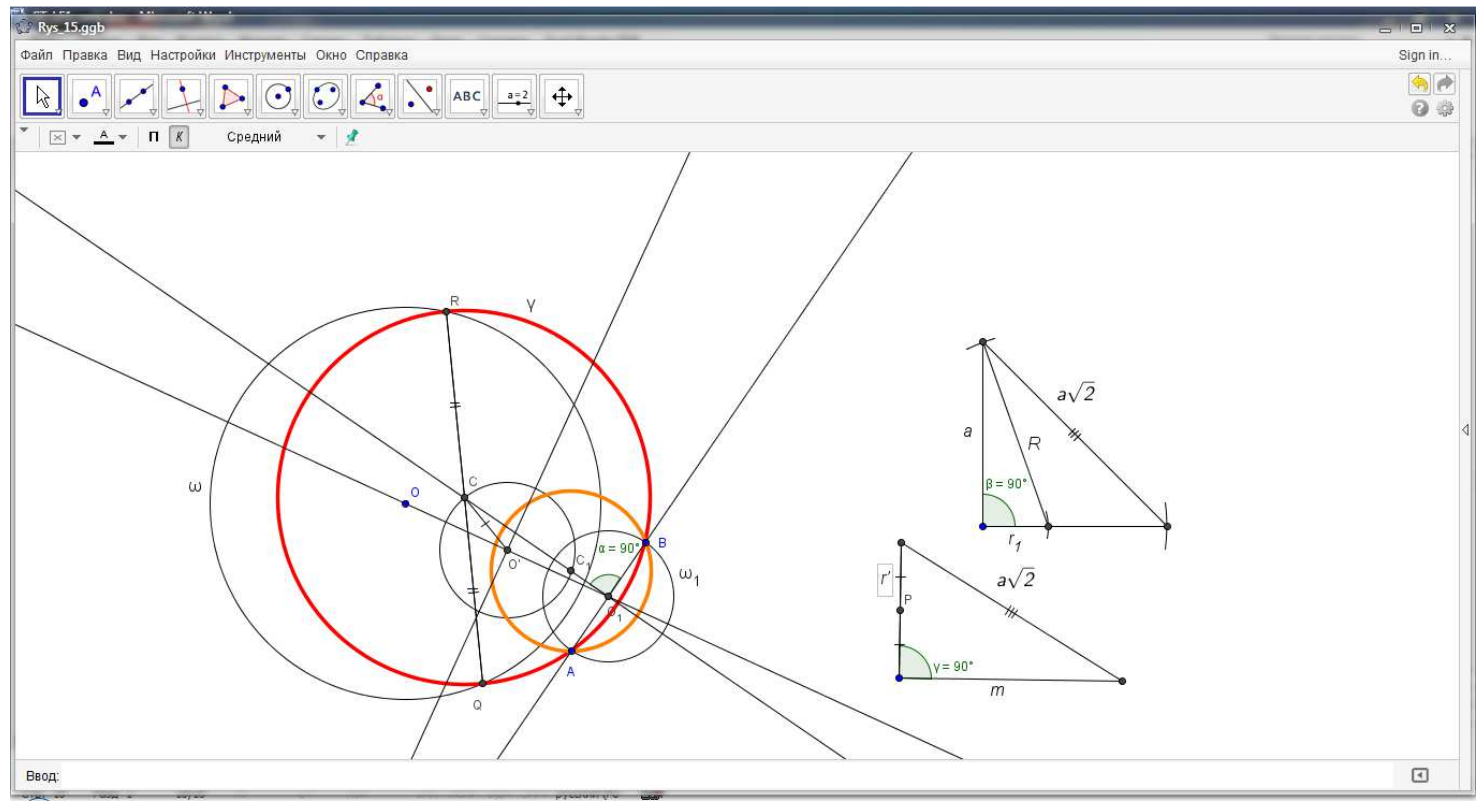

Рис. 18. Фрагмент зображення GeоGebra до задачі № 7 (в. 1) 
Окремими рисунками, на другому і п’ятому кроках побудов залучаємо до справи ще одну ОП: 12) побудова прямокутного трикутника за гіпотенузою і катетом.

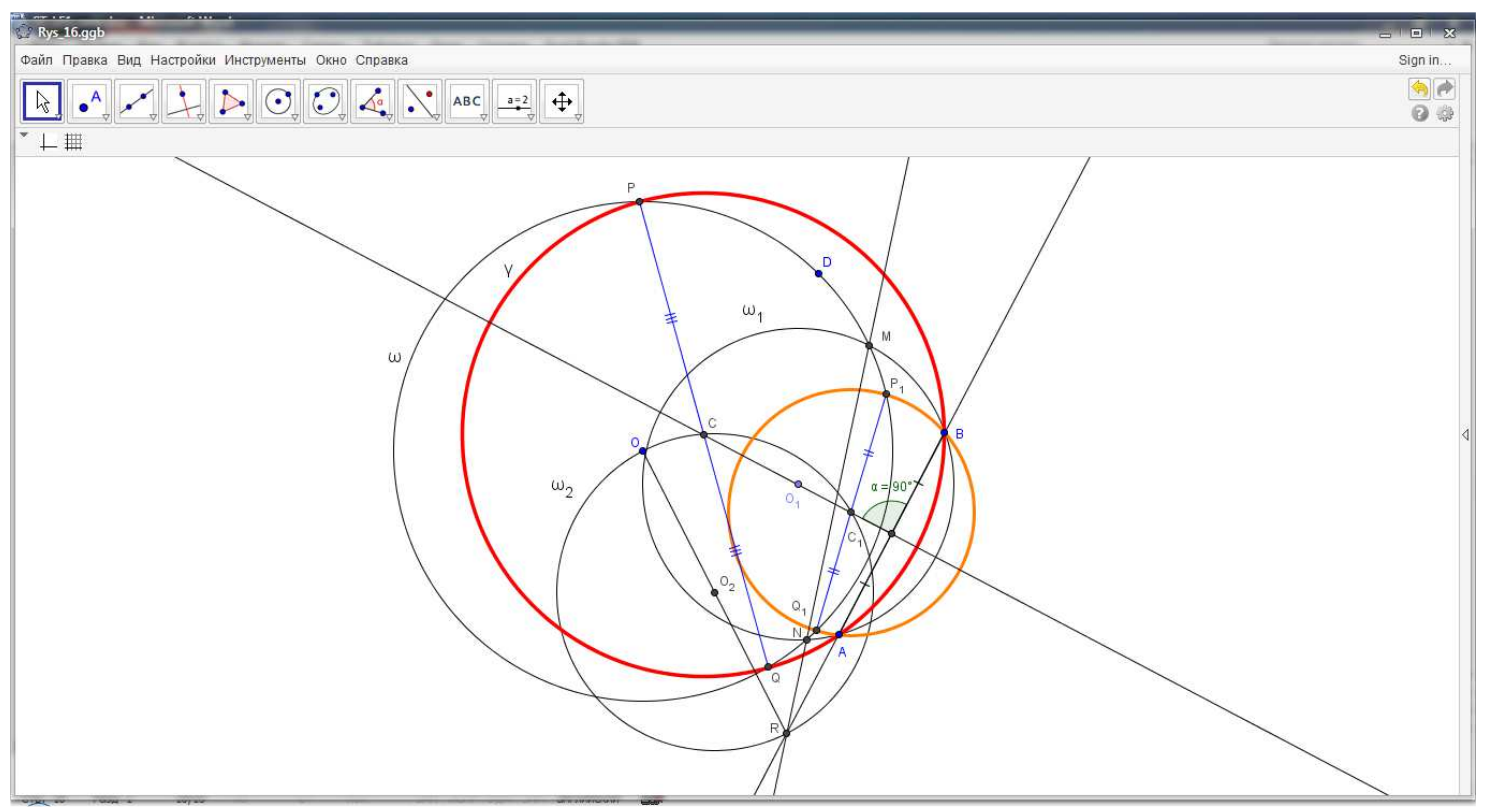

Рис. 19. Фрагмент зображення GeоGebra до задачі № 7 (в. 2)

Зараз конструктивну задачу розв'язано з ефективним використанням потужного апарату алгебри. Це, насправді, $є$ демонстрацією графоаналітичного методу в геометрії.

Варіант 2. Аналі з. Нехай коло $\gamma$ (рис. 17) задовольняє умову задачі - проходить через точки $A$ та $B$ і діаметрально перетинасться даним колом $\omega$ у точках $P$ i $Q$. Далі (див. задачу № 5, варіант 2) міркування з 1-го по 5-тий кроки алгоритму дій циркулем і лінійкою повторюються один до одного (не варто описувати їх ще раз). Завершувати ж пошук шляху розв'язання цієї задачі будемо дещо по-іншому. Оскільки потрібно знайти центр $C$ кола $\gamma$, інцидентний його діаметру (i хорді кола $\omega$ ) $P Q$, який належить ще одній радикальній осі $P-C-Q-\boldsymbol{R}$ в'язки кіл, залучених до операцій моделювання, а лінія центрів $O C$ пари кіл $\gamma$ і $\omega$ перпендикулярна цій радикальній осі [1, c. 74], то залишилося на відрізку $R O$, як на діаметрі, провести коло $\omega_{2}\left(O_{2}, O_{2} O=O_{2} R\right)(6)$ та знайти його перетини $C$ із серединним перпендикуляром відрізка $A B(7)$. Коло $\gamma(C, C P=C Q)-$ шукане (8). На моделі зображено два розв'язки задачі.

Отже, до розглядуваного типу належать також окремі задачі на перетини прямих і кіл.

\section{4. ВИСНОВКИ ТА ПЕРСПЕКТИВИ ПОДАЛЬШИХ ДОСЛІДЖЕНЬ}

Перелік задач, типових уже змодельованим вище, можна з успіхом продовжити, вимагаючи, за певних вихідних умов, побудувати приміром коло, яке діаметрально перетинає три дані кола, або коло - ортогональне до даного кола чи до двох (трьох) даних кіл, або коло, дотичні до якого з даних точок $A, B, C$ були б рівні відповідно трьом даним відрізкам $a, b, c$ і т. ін. Розв' язавши і залучивши до цього типу максимально можливу кількість задач, на завершення дослідження потрібно створити навчальну програму на метод кіл із тим, щоб суб'єкт учіння міг самостійно, «сидячи за комп'ютером» якісно опанувати тему «Пучки і в’язки кіл», набратися досвіду алгоритмічного мислення і візуального оперування прямими і колами у сфері закономірних зв'язків i відношень на основі конструктивного підходу. 
Зауважимо, що пік захоплення педагогів-геометрів предметно наповненими, глибоко змістовними задачами випадає на минуле століття, головним чином - на першу його половину. Причому, майже всі свої чудові книги науковці писали виключно для вчителів і студентів, кожна 3 яких нині $\epsilon$, фактично, бібліотечним раритетом. Проте в жодному 3 підручників, навчальному чи методичному посібнику з означеної тематики немає прозорої, вичерпно зрозумілої аргументації системного навчання планіметричних побудов. Принаймні, так проблема не ставиться, що не підкреслює змістової і фахової всеосяжності конструктивних задач, які необхідно містять характерні для всякої серйозної математичної пропозиції етапи розв'язування (аналіз, побудова, доведення, дослідження), їх абсолютної насиченості геометричними фактами, різноплановості та нестандартності в підходах до пошуку розв' язків. Не треба бути професіоналом геометрії, щоб «неозброєним оком» помітити факт: варіативність у виборі способу розв'язання задачі на побудову, серед інших позитивних якостей, $є$ одним із найбільш поцінованих і привабливих пріоритетів конструктивно-генетичного методу. Це - окраса диво-науки «Геометрія» те, що розвиває особистість, мотивує учіння.

Відомо, що кожна із 13-ти знаменитих книг Евкліда (330-275 рр. до н. е.) «Начала» розпочинається означеннями понять, які зустрічаються вперше; далі слідують аксіоми (постулати); за аксіомами йдуть теореми і задачі на побудову, розташовані в суворій послідовності так, що доведення (розв'язання) всякої наступної «пропозиції» спирається на попередню. 3 цього приводу О. В. Погорєлов писав: «Цей твір дає першу, що дійшла до нас, строго логічну побудову геометрії. Викладення в ньому настільки бездоганне для свого часу, що протягом двох тисяч років із моменту появи «Начал» він був єдиним посібником тим, хто вивчає геометрію» [14, с. 162]. Ось чому задачам на побудову в ЗОШ варто приділяти належну увагу не лише у процесі планової презентації курсу планіметрії, але й на його завершення - в 9-му класі. Це мали б бути підсумкові, узагальнюючі уроки наочно-образної демонстрації конструктивних можливостей усього розділу, зокрема — з ефективним використанням мультимедійної дошки.

Ми переконані, конструктивні задачі у викладанні й учінні евклідової геометрії відіграють особливу роль, вони - вершина найпершої з наук! Щоб уміло розв'язати кожну із задач, потрібно володіти повним багажем знань і вельми достатнім досвідом. У свою чергу, грунтовні знання і вміння, досвід можна здобути лише на теренах діяльнісного, дослідницького освітянського підходу, тобто шляхом регулярного розв'язування різного рівня складності творчих, різнохарактерних задач. Беззаперечно, постановку навчання геометрії з елементами фрагментарної типізації і педагогічно виваженого, доцільного використання сучасних ППЗ у комп'ютерному представленні задач на побудову слід вітати, оскільки це - інноваційний напрям роботи педагога-новатора. При тому задачам на прямі $\boldsymbol{i}$ кола в їх взаємних розташуваннях, дотиках і перетинах належить одне 3 провідних місць. Такі та схожі до них операції із природно «близькими» людині фігурами варті пильної уваги, здобуття навичок професійного виконання ще й тому, що у своїй переважній більшості вони мають практичний, прикладний характер.

\section{СПИСОК ВИКОРИСТАНИХ ДЖЕРЕЛ}

1. Аргунов Б. И. Геометрические построения на плоскости : учебное пособие для педагогических институтов / Б. И. Аргунов, М. В. Балк. - М. : Просвещение, 1966. $267 \mathrm{c}$.

2. Боравльов А. П. Аналіз у розв'язуванні задач на побудову : навчальний посібник для студентів ВПНЗ / А. П. Боравльов, І. Г. Ленчук. - К. : Вища школа, 2002. - 193 с.

3. Бурда М. І. Розв'язування задач на побудову в 6-8 класах : методичний посібник / М. І. Бурда. — К. : Радянська школа, 1986. — 112 с. 
4. Годик Е. И. Справочное руководство по черчению / Е. И. Годик, А. М. Хаскин. - М. : Машиностроение, 1974. - 696 с.

5. Жалдак М. I. Використання комп'ютера в навчальному процесі має бути педагогічно виваженим і доцільним / М. І. Жалдак // Комп’ютер у школі та сім’ї. - 2011. — № 3. - С. 312.

6. Жалдак М. І. Комп'ютер на уроках геометрії : посібник для вчителів / М. І. Жалдак, О. В. Вітюк. - К. РННЦ «ДІНІТ», 2004. - 168 с.

7. Зеленяк О. П. Технології застосування середовищ динамічної геометрії [Електронний ресурс] / О. П. Зеленяк // Інформаційні технології і засоби навчання. — 2013. — № 4 (36). — Режим доступу : http://journal.iitta.gov.ua.

8. Лемэръ Г. Методическое пособие к решению геометрических задач: Задачи на построение / Г. Лемэръ. - М. : Типо-литография Т-ва И. Н. Кушнерев и К ${ }^{0}, 1907 .-250$ с.

9. Ленчук I. Г. Системний підхід у навчанні планіметричним побудовам : навчальнометодичний посібник для студентів спеціальності «Педагогіка і методика середньої освіти. Математика» / І. Г. Ленчук. — Житомир : Вид-во ЖДУ ім. І. Франка, 2006. - 154 с.

10. Ленчук I. Г. Система навчання майбутнього вчителя конструктивної геометрії : монографія / І. Г. Ленчук. - Житомир : Вид-во ЖДУ ім. І. Франка, 2011. - 357 с.

11. Ленчук I. Г. Технологія типізації та комп'ютерного моделювання конструктивних задач планіметрії [Електронний ресурс] / І. Г. Ленчук, А. Ц. Франовський // Інформаційні технології і засоби навчання. — 2013. — № 6 (38). — Режим доступу : http://journal.iitta.gov.ua.

12.Михайленко В. Є. Зв’язки у викладанні геометрії і креслення у середній школі / В. Є. Михайленко, І. Ф. Тесленко. - К. : Радянська школа, 1965. — 85 с.

13.Михайленко В. Є. Інженерна та комп'ютерна графіка : підручник / В. Є. Михайленко. — К. : Каравелла, 2004. - 344 с.

14.Погорелов А. В. Геометрия : учебное пособие для студентов ВУЗов / А. В. Погорелов. - М. : Наука, 1983. - 288 с.

15. Раков С. А. Компьютерные эксперименты в геометрии / С. А. Раков, В. П. Горох. - Х. : РЦНИТ, 1996. - $176 \mathrm{c.}$

16. Ракута В. М. Система динамічної математики GeoGebra як інноваційний засіб для вивчення математики [Електронний ресурс] / В. М. Ракута // Інформаційні технології і засоби навчання. - 2012. - № 4 (30). — Режим доступу : http://journal.iitta.gov.ua.

17. Спірін О. М. Критерії і показники якості інформаційно-комунікаційних технологій навчання [Електронний ресурс] / О. М. Спірін // Інформаційні технології і засоби навчання. — 2013. — № 1 (33). — Режим доступу : http://journal.iitta.gov.ua.

18. Хаскин А. М. Черчение / А. М. Хаскин ; под ред. А. В. Блиока. - К. : Вища школа, 1979. $440 \mathrm{c}$.

19. Четверухин Н. Ф. Методы геометрических построений : учебное пособие для педагогических институтов / Н. Ф. Четверухин. - М. : Учпедгиз, 1952. - 148 с.

Матеріал надійшов до редакиіï 26.01.2014 p.

\title{
ТИПИЗАЦИЯ И КОМПЬЮТЕРНОЕ МОДЕЛИРОВАНИЕ КОНСТРУКТИВНЫХ ЗАДАЧ ПЛАНИМЕТРИИ: МЕТОД ОКРУЖНОСТЕЙ
}

\author{
Ленчук Иван Григорьевич \\ доктор педагогических наук, профессор, профессор кафедры обучения математики, физики и \\ информатики \\ Житомирский государственный университет имени Ивана Франко, г. Житомир, Украина \\ lench456@gmail.com \\ Франовский Анатолий Цезарович \\ кандидат физико-математических наук, доцент, декан физико-математического факультета \\ Житомирский государственный университет имени Ивана Франко, г. Житомир, Украина \\ integral52@mail.ru
}

Аннотация. Представленная статья касается задач на построение в планиметрии. Раскрыто
проблему становления у учащихся стереотипов эффективного, экономного во времени
визуального представления на экранах современных компьютеров алгоритмов решения
задач. Использован универсальный авторский прием фрагментарной типизации задач на 
метод окружностей. Выделены основные задачи данного типа с последующим их наполнением составляющими. Ранее разработанные педагогические программные средства (частично, GeoGebra) гарантируют оптимальную реализацию хода построений. Их динамические характеристики и конструктивные возможности - качественное нагляднообразное проведения этапов «доказательство» и « исследование».

Ключевые слова: метод окружностей; построение; конструктивная планиметрия; сопряжения; анализ; деятельный подход; моделирование; педагогические программные средства; типизация.

\title{
CLASSIFICATION AND COMPUTER SIMULATION OF CONSTRUCTIVE PROBLEM IN THE PLANE GEOMETRY: METHOD OF CIRCLES
}

\author{
Ivan H. Lenchuk \\ Doctor of pedagogical sciences, Professor, Professor of education in Mathematics, Physics and Informatics \\ Zhytomyr Ivan Franko State University, Zhytomyr, Ukraine \\ lench456@gmail.com
}

\author{
Anatolyii Ts. Franovskyi \\ Physical and Mathematical sciences, Associate Professor, Deccan of the Faculty of Physics and Mathematics \\ Zhytomyr Ivan Franko State University, Zhytomyr, Ukraine \\ integral52@mail.ru
}

\begin{abstract}
Presented article concerns construction problems in plane geometry. Solved the problem of the formation of students' stereotypes efficient, economical in time visual representation of algorithms for solving problems on the modern computer screens. Used universal author's method of fragmented typing tasks on the method of circles. Allocated the main problems of this type with their subsequent filling with ingredients. Previously developed educational software (partially, GeoGebra) ensure optimal realization of the construction. Their dynamic characteristics and constructive capabilities - quality visual- shaped stages of "evidence" and "research".
\end{abstract}

Keywords: method of circles; construction; constructive plane geometry; conjugation analysis;proactive approach; modeling; educational software; typing.

\section{REFERENCES (TRANSLATED AND TRANSLITERATED)}

1. Argunov B. I. Geometric constructions in the plane: Textbook for pedagogical institutes / B. I. Argunov, M. V. Balk. — M. : Education, 1966. — 267 p. (in Russian)

2. Boravlov A. P. The analysis in solving problems on construction: Teach. Guidance's for students. matemat. special-dren VPNZ / A. P. Boravlov, I. G. Lenchuk. — K. : High School, 2002. — 191 p. (in Ukrainian)

3. Burda M. I. Solving for the construction of 6-8 classrooms: Teacher / M. I. Burda. - K. : Soviet School, 1986. - 112 p. (in Ukrainian)

4. Godik E. I. Reference Manual for plotting / E. I. Godik, A. M. Khaskin. - M. : Mechanical Engineering, 1974. - 696 p. (in Russian)

5. Zhaldak M. I. Using the computer in the classroom should be well thought out and pedagogically appropriate / M. I. Zhaldak / / Computer for school and family. — 2011. — № 3. — P. 3-12. (in Ukrainian)

6. Zhaldak M. I. Computer lessons in geometry: Manual for teachers / M. I. Zhaldak, O. V. Vityuk. — K. : RNNTS "DINIT", 2004. - 168 p. (in Ukrainian)

7. Zelenyak O. P. Technologies use dynamic geometry environments [online] / O. P. Zelenyak // Information technology and learning tools. - 2013. - № 4 (36). — Available from : http://journal.iitta.gov.ua. (in Ukrainian)

8. Lemer G. Toolkit to solve geometric problems: Challenges for the construction / G. Lemer. - M. : Frame lithography T-va I. N. Kouchnerev and $\mathrm{K}^{0}, 1907 .-250$ p. (in Russian)

9. Lenchuk I. G. Systematic approach to teaching planimetric Built: Teach method. guidances. for students. special ones "Pedagogy and Methods of Secondary Education. Mathematics" / I. G. Lenchuk. - Exactly : Type of Waiting for them. Franko, 2006. - 154 p. (in Ukrainian) 
10. Lenchuk I. G. System teacher training future structural geometry: Monograph / I. G. Lenchuk. Exactly : Type of Waiting for them. Franko, 2011. - 357 p. (in Ukrainian)

11. Lenchuk I. G. Technology typing and computer simulation design tasks planimetry [online] / I. G. Lenchuk, A. Ts. Franovskyi // Information technology and learning tools. - 2013. — № 6 (38). - Available from : http://journal.iitta.gov.ua. (in Ukrainian)

12. Mikhaylenko V. E. Links in teaching geometry and drawing in high school / V. E. Mikhaylenko, I. F. Teslenko. - K. : Soviet School, 1965. — 85 p. (in Ukrainian)

13. Mikhaylenko V.E. Engineering and Computer Graphics: Tutorial / V.E. Mikhaylenko. — K. : Caravel, 2004. - 344 p. (in Ukrainian)

14. Pogorelov A. V. Geometry: Textbook for students / A. V. Pogorelov. — M. : Nauka, 1983. — 288 p. (in Russian)

15. Rakov S. A. Computer experiments in geometry / S. A. Rakov, V. P. Gorokh. - Kharkov : RTSNIT, 1996. - 176 p. (in Ukrainian)

16. Rakuta V. M. GeoGebra Dynamic mathematics as an innovative tool for learning mathematics [online] / V. M. Rakuta // Information technology and learning tools. - 2012. — № 4 (30). Available from : http://journal.iitta.gov.ua. (in Ukrainian)

17. Spirin O. M. Criteria and indicators of quality of ICT learning [online] / O. M. Spirin // Information technology and learning tools. — 2013. — № 1 (33). — Available from : http://journal.iitta.gov.ua. (in Ukrainian)

18. Khaskin A. M. Cherchenye / A. M. Khaskin, under the editorship A. V. Blioka. - K. : High School, 1979. - 440 p. (in Ukrainian)

19. Chetverukhin N. F. Methods heometrycheskyh postroenyy: Textbook for pedagogical ynstytutov / N. F. Chetverukhin. - M. : Uchpedhyz, 1952. — 148 p. (in Russian) 